\title{
SISTEM PENDUKUNG KEPUTUSAN PEMILIHAN FINALIS DUTA BAHASA SUMATERA UTARA DENGAN MENGGUNAKAN METODE PROMETHEE II (STUDI KASUS: BALAI BAHASA SUMATERA UTARA)
}

\author{
Cristella Sitinjak ${ }^{1}$, Nelly Astuti Hasibuan², Rian Syahputra ${ }^{3}$
}

\author{
Program Studi Teknologi Informatika STMIK Budi Darma,Medan, Indonesia
}

Email: cristellasitinjak1@gmail.com

\begin{abstract}
Abstrak
Proses pemilihan Finalis Duta Bahasa Sumatera Utara pada Balai Bahasa Sumatera Utara masih bersifat subjektif dimana penilaian bisa saja tidak berdasarkan kriteria yang telah di tetapkan atau tanpa melihat secara objektif sehingga proses pemilihan yang dilakukan kurang begitu tepat dan keputusan yang dihasilkan kurang memuaskan bagi para peserta Finalis Duta Bahasa Sumatera Utara. Dalam penelitian ini, penulis menggunakan sistem pendukung keputusan dengan metode Promethee II untuk mencari nilai bobot dan kriteria, dan untuk mencari nilai akhir ataupun untuk mencari nilai perankingan Finalis Duta Bahasa Sumatera Utara. Dengan demikian Sistem Pendukung Keputusan sangat dibutuhkan agar dapat membantu pihak Balai Bahasa Sumatera Utara dalam menentukan Finalis Duta Bahasa Sumatera Utara. Mengatasi permasalahan tersebut, maka perlu dibangun aplikasi sistem pendukung keputusan pemilihan Finalis Duta Bahasa Sumatera Utara dengan menggunakan metode Promethee II sehingga dapat membantu dan mempermudah pihak Balai Bahasa Sumatera Utara dalam pengambilan keputusan memilih Duta Bahasa Sumatera Utara dan keputusan yang ditetapkan hasilnya memuaskan.
\end{abstract}

Kata kunci: Sistem Pendukung Keputusan, Duta Bahasa, Metode Promethee ii

\begin{abstract}
The process of selecting the North Sumatra Ambassador Language Finalists at the North Sumatra Language Hall is still subjective in that the assessment may not be based on established criteria or without looking objectively so that the selection process is carried out less precisely and the resulting decision is less satisfactory for the participants of the Ambassador Finalists North Sumatra Language. In this study, the authors used a decision support system with the Promethee II method to find the value of weights and criteria, and to find the final score or to find the finalist ranking of the North Sumatra Language Ambassador. Thus the Decision Support System is needed in order to help the North Sumatra Language Office in determining the Finalists of the North Sumatra Language Ambassador. To overcome these problems, it is necessary to build a decision support system application for the selection of North Sumatra Language Ambassador Finalists using the Promethee II method so that it can help and facilitate the North Sumatra Language Hall in making a decision to choose the North Sumatra Language Ambassador and the resulting decision is satisfactory.
\end{abstract}

Keywords: Decision Support System, Language Ambassadors, Promethee Method ii

\section{PENDAHULUAN}

Budaya berbahasa Indonesia dengan baik dan benar sudah sangat jarang dilakukan. Hal ini dikarenakan masuknya zaman era modern yang membawa dampak buruk bagi generasi bangsa Indonesia sehingga membuat sejumlah generasi Indonesia menjadi kurang memahami dalam penggunaan Bahasa Indonesia yang baik dan benar. Banyak generasi yang kurang perduli akan bahasa dari Negaranya sendiri dan lebih tertarik untuk menggunakan bahasa dari luar negaranya dalam kehidupan sehari-hari. Balai Bahasa Sumatera Utara adalah salah satu instansi yang dijadikan sebagai tempat untuk pengembangan dan pembinaan bahasa (Badan Bahasa) yang berfungsi untuk menangani suatu permasalahan yang berhubungan dalam kebahasaan dan kesastraan di Indonesia. Balai Bahasa Sumatera Utara banyak melakukan beberapa program kerja yang nantinya dijadikan untuk agen promosi dalam upaya pelestarian Bahasa Indonesia salah satunya adalah pemilihan Duta Bahasa.

Duta Bahasa merupakan seorang yang memiliki tanggung jawab untuk upaya dalam membantu melestarikan Bahasa serta turut berperan penting dalam upaya membina, melindungi, dan mengembangkan Bahasa Indonesia dan membantu badan atau Balai Bahasa dalam upaya mengkampanyekan penting dan luhurnya Bahasa Indonesia. Balai Bahasa Sumatera Utara setiap tahunnya telah melakukan pemilihan Duta Bahasa Sumatera Utara, akan tetapi dalam pemilihan yang dilakukan tersebut belum ada sistem yang membantu dalam proses pemilihan sehingga dalam proses pemilihan bersifat subjektif dimana penilaian bisa saja tidak berdasarkan kriteria yang telah di tetapkan atau tanpa melihat secara objektif sehingga proses pemilihan yang dilakukan kurang begitu tepat dan keputusan yang dihasilkan kurang memuaskan bagi peserta. Salah satu solusi untuk memilih Finalis Duta Bahasa adalah dengan membuat sistem pendukung keputusan.

Sistem Pendukung Keputusan (SPK) merupakan bagian dari Sistem informasi yang berbasis komputer yang dapat membantu dalam pengambilan suatu keputusan, yang dapat mempermudah dalam pemecahan suatu masalah untuk pengambilan suatu keputusan terstruktur maupun tidak terstruktur. SPK ini bertujuan untuk memberikan informasi, dan juga berupa solusi untuk melakukan pengambilan suatu keputusan dengan baik dan benar. Dengan adanya SPK, maka akan mempermudah didalam menentukan suatu keputusan dengan hasil yang terbaik. Di dalam SPK untuk menentukan pembobotan dan melakukan perengkingan dapat digunakan metode Promethee II[1].

\section{TEORITIS}




\subsection{Sistem Pendukung Keputusan}

Moore dan Chang berpendapat bahwa Sistem Pendukung Keputusan dapat menangani situasi semistruktural dan tidak terstruktural, sebuah masalah dijelaskan sebagai masalah terstruktural dan tidak terstruktural hanya dengan memperhatikan si pengambil keputusan atau suatu spesifik[2]. Little mendefinisikan Sistem Pendukung Keputusan sebagai suatu informasi berbasis komputer yang menghasilkan berbagai alternatif keputusan untuk membantu manajemen dalam menangani berbagai permasalahan yang terstruktur maupun tidak terstruktur dengan menggunakan data dan model[3]. Dari berbagai defenisi menurut para ahli diatas dapat disimpulkan bahwa Sistem Pendukung Keputusan adalah suatu sistem informasi spesifikasi yang ditujukan untuk membantu manajemen dalam mengambil keputusan yang berkaitan dengan persoalan yang bersifat semi struktural dan struktural.

\subsection{Duta Bahasa}

Duta adalah seseorang yang dipilih untuk tugas tertentu yang bertugas untuk mewakili organisasi ataupun mempromosikan suatu bidang tertentu. Duta juga dapat diartikan sebagai tokoh yang menjadi icon dalam masyarakat yang memahami benar segala aspek baik dalam objeknya maupun subjeknya. Duta Bahasa adalah tokoh atau icon yang menjadi pelopor dalam hal yang berhubungan dengan bahasa dan sastra Indonesia[4].

Bahasa adalah adalah kemampuan yang dimiliki manusia untuk berkomunikasi dengan manusia lainnya menggunakan tanda, misalnya kata dan gerakan. Atau alat untuk beriteraksi dan berkomunikasi, dalam arti alat untuk menyampaikan pikiran, gagasan, konsep atau perasaan[5].

Duta Bahasa merupakan seseorang yang memiliki tanggung jawab untuk upaya dalam membantu melestarikan Bahasa. Duta Bahasa juga turut berperan penting dalam upaya membina, melindungi, dan mengembangkan Bahasa Indonesia serta membantu Badan atau Balai Bahasa dalam upaya mengkampanyekan pentingnya berbudaya Bahasa Indonesia dengan baik dan benar[6].

\subsection{Metode Promethee ii}

Metode Promethee ii (Preference Ranking Organization Method For Enrichmen Evaluation ii) merupakan metode yang memiliki bagian yang lebih dikembangkan seperti Promethee I yang digunakan untuk menghitung peringkat parsial dari alternatif dan promethee II yang digunakan untuk melakukan penentuan atau pengurutan dalam suatu analisis kriteria. Pada bagian ini hanya dijelaskan Metode Promethee II atau dikenal dengan nama Preference Ranking Organization Method For Enrichmen Evaluation II. Metode Promethee II dapat memperoleh rangking lengkap dari alternatifnya. Metode promethee II melakukan pendekatan pengambilan keputusan multi kriteria yang interaktif yang dirancang untuk menangani kriteria kuantitatif dengan alternatif diskrit. Dalam metode ini perbandingan dua alternatif dilakukan untuk menghitung fungsi preferensi untuk setiap kriteria[7].

Berikut langkah-langkah penyelesaian masalah dengan Metode Promethee II sebagai berikut[8] :

1. Menormalisasikan matriks keputusan dengan menggunakan persamaan sebagai berikut :

$R i j=[X i j-\min (X i j)] /[\max \quad(X i j-\min i(X i j)]$

Untuk mencari kriteria cost dapat dituliskan ulang sebagai berikut ini;

$R i j=[\max (X i j)-X i j] /[\max ; 0:(X i j-\min ; 0:(X i j)]$

$$
\begin{array}{lll}
\text { Keterangan : } & \text { Rij } & =\text { Matriks ternormalisasi } \\
& \text { Xij min } & =\text { Nilai minimum } x i j \\
& \text { Xij max } & =\text { Nilai maksimum } x i j
\end{array}
$$

2. Menghitung fungsi preferensi $\mathrm{Pj}(\mathrm{i}, \mathrm{i})$

fungsi preferensi ini memerlukan definisi beberapa parameter preferensial, seperti preferensi dan batasan ketidakpedulian. Namun, dalam aplikasi real time, mungkin sulit bagi pengambil keputusan untuk menentukan fungsi preferensi spesifik yang sesuai untuk setiap kriteria dan juga untuk menentukan parameter yang terlibat. Adapun rumus yang digunakan yaitu;

$$
\begin{array}{ll}
\left(\mathrm{i}, \mathrm{i}^{\prime}\right) & =0 \mathrm{jika} R i j \leq R i^{\prime} j \\
P j\left(\mathrm{i}, \mathrm{i}^{\prime}\right) & =\left(R i j-R i^{\prime} j\right)
\end{array}
$$

Keterangan : i,i $\quad=$ Alternatif yang akan dipasangkan

$\operatorname{Pj}\left(\mathrm{i}, \mathrm{i}^{\prime}\right)=$ Alternatif yang akan dipasangkan

3. Menghitung fungsi preferensi agregat dengan mempertimbangkan bobot kriteria.

Fungsi preferensi agregat

$\left(\mathrm{i}, \mathrm{i}^{\prime}\right)=\left[\Sigma W j m j=1 \cdot P j\left(i, i^{\prime}\right)\right] / \Sigma W j m j=1$

Keterangan : i,i' = Alternatif yang akan dipasangkan

$$
\mathrm{WP}=\text { Weak Preference }
$$

$$
\begin{aligned}
& \mathrm{mj}=\text { Jumlah kriteria } \\
& \qquad W_{j}=\text { Bobot kriteria } j
\end{aligned}
$$

4. Tentukan arus keluar dan arus outranking sebagai berikut:

Mencari arus leaving flow: 
(i) $=1 n-1\left[\Sigma \pi n i^{\prime}=1\left(i, i^{\prime}\right)\right] /(\mathrm{i} \neq i)$

Mencari arus entring flow:

(i) $\quad=1 n-1\left[\Sigma \pi n i^{\prime}=1\left(i, i^{\prime}\right)\right] /(\mathrm{i} \neq i)$

$$
\begin{aligned}
& \text { Keterangan: } i=\text { alternatif } \\
& i \text {, = alternatif yang dipasangkan } \\
& \mathrm{m} \quad=\text { jumlah alternatif } \\
& \mathrm{n} \quad=\text { jumlah kriteria }
\end{aligned}
$$

5. Hitung arus outranking bersih untuk setiap alternatif.

$(i)=\varphi+(\mathrm{i})-\varphi-(\mathrm{i})$

Keterangan : $\varphi+\quad=$ Nilai leaving flow

$\varphi^{-} \quad=$ Nilai entering flow

\section{ANALISA DAN PEMBAHASAN}

\subsection{Analisa}

Prosedur dalam pemilihan Finalis Duta Bahasa Sumatera Utara pada Balai Bahasa Sumatera Utara hanya berdasarkan kriteria-kriteria tertentu sehingga hasil yang ditetapkan bersifat subjektif. Berdasarkan penelitian yang dilakukan pada Balai Bahasa Sumatera Utara, prosedur pemilihan Finalis Duta Bahasa Sumatera Utara dimulai dengan proses pendaftaran peserta Duta Bahasa, selanjutnya pengumuman hasil seleksi berkas, setelah pengumuman hasil seleksi berkas maka akan dilakukan proses seleksi wawancara, kemudian pengumuman hasil seleksi wawancara, selanjutnya tes ujian Kemahiran Berbahasa Indonesia (UKBI), lalu akan diumumkan 20 besar Finalis yang lolos ke tahap berikutnya, selanjutnya 20 besar Finalis Duta Bahasa akan mengikuti masa Karantina dan pada tahap terakhir akan diumumkan pemenang yang terpilih sebagai Duta Bahasa Sumatera Utara sebanyak 2 orang yakni laki-laki dan perempuan yang dipilih langsung oleh para dewan juri Duta Bahasa Sumatera Utara 2019. Kriteria-kriteria penilaian yang ditetapkan oleh panitia pemilihan Duta Bahasa Sumatera Utara 2019 yaitu: Etika, Kemampuan Berbahasa, Pendidikan, Prestasi, dan Umur.

Proses pemilihan Finalis Duta Bahasa Sumatera Utara pada Balai Bahasa Sumatera Utara masih bersifat subjektif, belum ada sistem yang membantu dalam proses pemilihan. Agar proses pemilihan Duta Bahasa Sumatera Utara dapat dilakukan dengan lebih akurat serta dapat bersifat objektif, maka diperlukan Sistem Pendukung Keputusan (SPK) yang dapat membantu mempermudah dalam melakukan pemilihan Finalis Duta Bahasa Sumatera Utara. Salah satu metode dalam Sistem Pendukung Keputusan yang dapat digunakan untuk pemilihan Finalis Duta Bahasa Sumatera Utara yaitu dengan menggunakan metode Promethee ii.

\subsection{Pembahasan}

Data alternatif-alternatif yang menjadi peserta Duta Bahasa Sumatera Utara pada Balai Bahasa Sumatera Utara.

Tabel 1. Alternatif

\begin{tabular}{cc}
\hline Kode & Nama Alternatif \\
\hline A1 & Hamsah Aulia Pohan \\
A2 & Adinda Isna Batubara \\
A3 & Friska Situmorang \\
A4 & Jikti Khairina \\
A5 & Difadila Malindo \\
A6 & Muhammad Yunus \\
A7 & Herianto Silalahi \\
A8 & Patrial Olivert Zega \\
A9 & Gus Indah Hardiyanti Giawa \\
A10
\end{tabular}

Kriteria-kriteria dan bobot yang telah ditetapkan oleh panitia penyelenggara pemilihan Duta Bahasa Sumatera Utara pada Balai Bahasa Sumatera Utara.

Tabel 2. Kriteria dan Bobot

\begin{tabular}{clc}
\hline Kode & \multicolumn{1}{c}{ Nama } & Bobot \\
\hline $\mathrm{C} 1$ & Etika $(\mathrm{E})$ & $35 \%$ Benefit \\
$\mathrm{C} 2$ & Kemampuan Berbahasa $(\mathrm{KB})$ & $25 \%$ Benefit
\end{tabular}




$\begin{array}{llc}\text { C3 } & \text { Pendidikan (PD) } & 20 \% \text { Benefit } \\ \text { C4 } & \text { Prestasi (PS) } & 15 \% \text { Benetif } \\ \text { C5 } & \text { Umur (U) } & 5 \% \text { Benefit }\end{array}$

Keterangan:

- $\quad$ Benefit merupakan bentuk imbalan jasa atau dasar kebutuhan yang berguna untuk memperlancar proses kerja sama.

- $\quad$ Cost merupakan kerugian yang dilakukan selama proses distribusi yang dinyatakan dalam bentuk satuan harga.

Dari kriteria yang telah ditentukan dan rating kecocokan dari pada setiap alternatif yang ada pada setiap kriteria yang telah ditentukan untuk mendapatkan variabel dari setiap kriteria harus dibuat dalam bentuk sebuah grafik untuk lebih jelas dapat dilihat pada gambar 1.

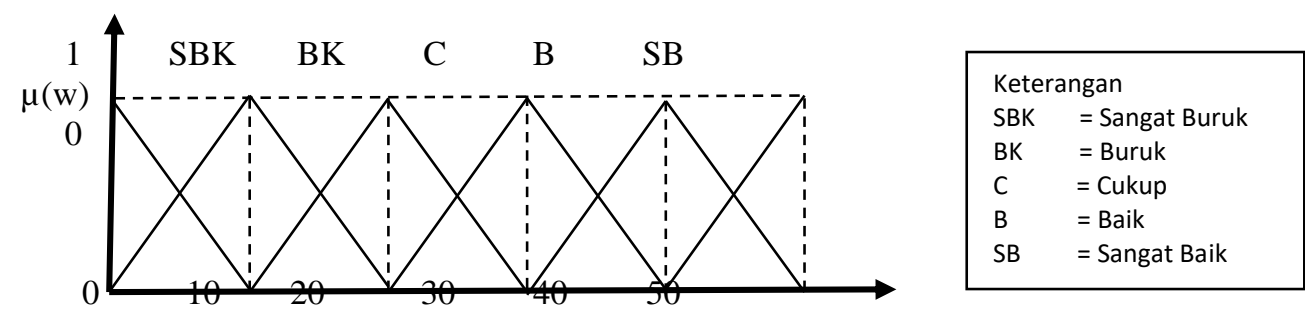

Gambar 1 Grafik Fuzzy Bobot

Dari gambar diatas, bilangan-bilangan fuzzy dapat dikonversikan ke bilangan crisp.

Tabel 3. Bobot

\begin{tabular}{cc}
\hline Bilangan fuzzy & Nilai \\
\hline Sangat Buruk (SBK) & 10 \\
Buruk (B) & 20 \\
Cukup (C) & 30 \\
Baik (B) & 40 \\
Sangat Baik (SB) & 50 \\
\hline
\end{tabular}

Berikut ini penjelasan dan nilai dari kriteria yang dipakai dalam sistem pendukung keputusan pemilihan Finalis Duta Bahasa Sumatera Utara sebagai berikut:

1. Di Balai Bahasa Sumatera Utara, Etika merupakan kunci utama yang harus dimiliki oleh setiap peserta Duta Bahasa. Etika adalah aturan mengenai sikap atau perilaku dilingkungan sesuai dengan kebiasaan ditempat dimana ia berada. Penilaian Etika dilakukan pada saat diwawancara dan masa karantina. Penilaiannya adalah kepribadian dan penampilan. Tabel Etika dapat dilihat pada tabel 4.

Tabel 4. Kriteria Etika

\begin{tabular}{lcc}
\hline \multicolumn{1}{c}{ Etika (C1) } & Bilangan Fuzzy & Nilai \\
\hline Kepribadian dan Penampilan sangat buruk & Sangat Buruk & 10 \\
Kepribadian dan Penampilan buruk & Buruk & 20 \\
Kepribadian dan Penampilan cukup & Cukup & 30 \\
Kepribadian dan Penampilan baik & Baik & 40 \\
Kepribadian dan Penampilan sangat baik & Sangat Baik & 50 \\
\hline
\end{tabular}

2. Kemampuan Berbahasa dijadikan penilaian yang kedua yang menjadi salah satu kriteria yang harus dimiliki oleh setiap peserta Duta Bahasa. Adapun yang menjadi penilaian dalam Kemampuan Berbahasa yakni kemampuan Berbahasa Daerah, Kemampuan Berbahasa Indonesia, dan kemampuan Berbahasa Asing. Penilaian Kemampuan Berbahasa dapat dilihat pada tabel dibawah ini:

Tabel 5. Kemampuan Berbahasa

\begin{tabular}{lcc}
\hline Kemampuan Berbahasa (C2) & Bilangan Fuzzy & Nilai \\
\hline Bahasa Indonesia & Sangat Buruk & 10 \\
Bahasa Indonesia, Bahasa Daerah & Buruk & 20 \\
Bahasa Indonesia, Bahasa Asing & Cukup & 30 \\
Bahasa Indonesia, Bahasa Daerah, Bahasa Asing & Baik & 40 \\
Lebih dari 4 Bahasa & Sangat Baik & 50 \\
\hline
\end{tabular}


3. Peserta Duta Bahasa Sumatera Utara harus memiliki pendidikan yang layak. Pendidikan adalah pembelajaran pengetahuan yang diturunkan dari generasi ke generasi selanjutnya melalui pengajaran, pelatihan, atau penelitian. Penilaian Pendidikan dapat dilihat pada tabel dibawah ini:

Tabel 6. Pendidikan

\begin{tabular}{ccc}
\hline Pendidikan $(\mathrm{C} 3)$ & Keterangan & Nilai \\
\hline S1/D3 & Sangat Baik & 50 \\
SMA/SMK & Baik & 40 \\
\hline
\end{tabular}

4. Prestasi merupakan penghargaan hasil usaha yang telah dikerjakan oleh seseorang dapat berupa kemampuan dari ajang-ajang yang diikutinya. Adapun uraian prestasi yaitu Prestasi tingkat Internasional, Prestasi tingkat Nasional, Prestasi tingkat Provinsi, dan Prestasi tingkat Kabupaten, Prestasi Kecamatan. Penilaian prestasi dapat dilihat pada tabel dibawah ini:

Tabel 7. Prestasi

\begin{tabular}{ccc}
\hline Prestasi (C4) & Bilangan Fuzzy & Nilai \\
\hline Kecamatan & Sangat Buruk & 10 \\
Kabupaten & Buruk & 20 \\
Provinsi & Cukup & 30 \\
Nasional & Baik & 40 \\
Internasional & Sangat Baik & 50 \\
\hline
\end{tabular}

Nilai alternatif merupakan nilai yang sudah ditentukan untuk setiap alternatif yang sebelumnya ditampilkan tabel nilai alternatif untuk setiap kriteria, tampilan tabel sebagai berikut:

Tabel 8. Nilai Alternatif Untuk Setiap Kriteria

\begin{tabular}{lccccc}
\hline \multicolumn{1}{c}{ Alternatif } & \multicolumn{4}{c}{ Kriteria } \\
\cline { 2 - 5 } & E & KB & PD & PS & U \\
\hline Hamsah Aulia Pohan & Baik & Sangat Baik & 40 & 40 & 21 Tahun \\
Muhammad Hisyamsyah Dani & Cukup Baik & Baik & 50 & 30 & 22 Tahun \\
Adinda Isna Batubara & Baik & Sangat Baik & 40 & 30 & 19 Tahun \\
Friska Situmorang & Sangat Baik & Sangat Baik & 40 & 50 & 21 Tahun \\
Jikti Khairina & Baik & Baik & 40 & 40 & 20 Tahun \\
Difadila Malindo & Baik & Cukup & 40 & 40 & 20 Tahun \\
Muhammad Yunus & Cukup Baik & Baik & 40 & 30 & 20 Tahun \\
Herianto Silalahi & Sangat Baik & Sangat Baik & 40 & 40 & 20 Tahun \\
Patrial Olivert Zega & Baik & Sangat Baik & 50 & 50 & 21 Tahun \\
Gus Indah Hardiyanti Giawa & Baik & Cukup & 40 & 40 & 21 Tahun \\
\hline
\end{tabular}

Tabel 9. Rating Kecocokan Alternatif dan Kriteria

\begin{tabular}{llllll}
\hline & C1 & C2 & C3 & C4 & C5 \\
\hline A1 & 40 & 50 & 40 & 40 & 21 \\
A2 & 30 & 40 & 50 & 30 & 22 \\
A3 & 40 & 50 & 40 & 30 & 19 \\
A4 & 50 & 50 & 40 & 50 & 21 \\
A5 & 40 & 40 & 40 & 40 & 20 \\
A6 & 40 & 30 & 40 & 40 & 20 \\
A7 & 30 & 40 & 40 & 30 & 20 \\
A8 & 50 & 50 & 40 & 40 & 20 \\
A9 & 40 & 50 & 50 & 50 & 21 \\
A10 & 40 & 30 & 40 & 40 & \\
\hline
\end{tabular}

$$
\mathrm{C}=\left[\begin{array}{lllll}
40 & 50 & 40 & 40 & 21 \\
30 & 40 & 50 & 30 & 22 \\
40 & 50 & 40 & 30 & 19 \\
50 & 50 & 40 & 50 & 21 \\
40 & 40 & 40 & 40 & 20 \\
40 & 30 & 40 & 40 & 20 \\
30 & 40 & 40 & 30 & 20 \\
50 & 50 & 40 & 40 & 20 \\
40 & 50 & 50 & 50 & 21 \\
40 & 30 & 40 & 40 & 21
\end{array}\right]
$$


Setelah melalui tahap pencarian nilai pada setiap Alternatif untuk peserta Finalis Duta Bahasa Sumatera Utara selanjutnya akan dilakukan proses pencarian hasil dengan menggunakan metode Promethee II. Adapun tahap proses pencariannya adalah sebagai berikut:

1. Menormalisasikan matriks keputusan dengan menggunakan persamaan 1 , sebagai berikut :

Dimana $\quad \operatorname{Max}(\mathrm{Xij})=\mathrm{C} 1=50, \mathrm{C} 2=50, \mathrm{C} 3=50, \mathrm{C} 4=50, \mathrm{C} 5=22$

$\operatorname{Min}(\mathrm{Xij})=\mathrm{C} 1=30, \mathrm{C} 2=30, \mathrm{C} 3=40, \mathrm{C} 4=30, \mathrm{C} 5=19$

\begin{tabular}{lllll}
$\mathrm{C} 1=$ Etika & $\mathrm{C} 2=$ Kemampuan & $\mathrm{C} 3=$ Pendidikan & $\mathrm{C} 4=$ Prestasi & $\mathrm{C} 5=$ Umur \\
$\mathrm{R}_{11}=\frac{[40-30]}{[50-30]}=0.5$ & $\mathrm{R}_{12}=\frac{[50-30]}{[50-30]}=1$ & $\mathrm{R}_{13}=\frac{[40-40]}{[50-40]}=0$ & $\mathrm{R}_{14}=\frac{[40-30]}{[50-30]}=0.5$ & $\mathrm{R}_{15}=\frac{[21-19]}{[22-19]}=0.67$ \\
$\mathrm{R}_{21}=\frac{[30-30]}{[50-30]}=0$ & $\mathrm{R}_{22}=\frac{[40-30]}{[50-30]}=0.5$ & $\mathrm{R}_{23}=\frac{[50-40]}{[50-40]}=1$ & $\mathrm{R}_{24}=\frac{[30-30]}{[50-30]}=0$ & $\mathrm{R}_{25}=\frac{[22-19]}{[22-19]}=1$ \\
$\mathrm{R}_{31}=\frac{[40-30]}{[50-30]}=0.5$ & $\mathrm{R}_{32}=\frac{[50-30]}{[50-30]}=1$ & $\mathrm{R}_{33}=\frac{[40-40]}{[50-40]}=0$ & $\mathrm{R}_{34}=\frac{[30-30]}{[50-30]}=0$ & $\mathrm{R}_{35}=\frac{[19-19]}{[22-19]}=0$ \\
$\mathrm{R}_{41}=\frac{[50-30]}{[50-30]}=1$ & $\mathrm{R}_{42}=\frac{[50-30]}{[50-30]}=1$ & $\mathrm{R}_{43}=\frac{[40-40]}{[50-40]}=0$ & $\mathrm{R}_{44}=\frac{[50-30]}{[50-30]}=1$ & $\mathrm{R}_{45}=\frac{[21-19]}{[22-19]}=0.67$ \\
$\mathrm{R}_{51}=\frac{[40-30]}{[50-30]}=0.5$ & $\mathrm{R}_{52}=\frac{[40-30]}{[50-30]}=0.5$ & $\mathrm{R}_{53}=\frac{[40-40]}{[50-40]}=0$ & $\mathrm{R}_{54}=\frac{[40-30]}{[50-30]}=0.5$ & $\mathrm{R}_{55}=\frac{[20-19]}{[22-19]}=0.33$ \\
$\mathrm{R}_{61}=\frac{[40-30]}{[50-30]}=0.5$ & $\mathrm{R}_{62}=\frac{[30-30]}{[50-30]}=0$ & $\mathrm{R}_{63}=\frac{[40-40]}{[50-40]}=0$ & $\mathrm{R}_{64}=\frac{[40-30]}{[50-30]}=0.5$ & $\mathrm{R}_{65}=\frac{[20-19]}{[22-19]}=0.33$ \\
$\mathrm{R}_{71}=\frac{[30-30]}{[50-30]}=0$ & $\mathrm{R}_{72}=\frac{[40-30]}{[50-30]}=0.5$ & $\mathrm{R}_{73}=\frac{[40-40]}{[50-40]}=0$ & $\mathrm{R}_{74}=\frac{[30-30]}{[50-30]}=0$ & $\mathrm{R}_{75}=\frac{[20-19]}{[22-19]}=0.33$ \\
$\mathrm{R}_{81}=\frac{[50-30]}{[50-30]}=1$ & $\mathrm{R}_{82}=\frac{[50-30]}{[50-30]}=1$ & $\mathrm{R}_{83}=\frac{[40-40]}{[50-40]}=0$ & $\mathrm{R}_{84}=\frac{[40-30]}{[50-30]}=0.5$ & $\mathrm{R}_{85}=\frac{[20-19]}{[22-19]}=0.33$ \\
$\mathrm{R}_{91}=\frac{[40-30]}{[50-30]}=0.5$ & $\mathrm{R}_{92}=\frac{[50-30]}{[50-30]}=1$ & $\mathrm{R}_{93}=\frac{[50-40]}{[50-40]}=1$ & $\mathrm{R}_{94}=\frac{[50-30]}{[50-30]}=1$ & $\mathrm{R}_{95}=\frac{[21-19]}{[22-19]}=0.67$ \\
$\mathrm{R}_{101}=\frac{[40-30]}{[50-30]}=0.5$ & $\mathrm{R}_{102}=\frac{[50-30]}{[50-30]}=0$ & $\mathrm{R}_{103}=\frac{[40-40]}{[50-40]}=0$ & $\mathrm{R}_{104}=\frac{[40-30]}{[50-30]}=0.5$ & $\mathrm{R}_{105}=\frac{[21-19]}{[22-19]}=0.67$ \\
\hline
\end{tabular}

Matriks keputusan yang ternormalisasi dibuat dari hasil normalisasi atas adalah sebagai berikut :

$\left[\begin{array}{ccccc}0,5 & 1 & 0 & 0,5 & 0,67 \\ 0 & 0,5 & 1 & 0 & 1 \\ 0,5 & 1 & 0 & 0 & 0 \\ 1 & 1 & 0 & 1 & 0,67 \\ 0,5 & 0,5 & 0 & 0,5 & 0,33 \\ 0,5 & 0 & 0 & 0,5 & 0,33 \\ 0 & 0,5 & 0 & 0 & 0,33 \\ 1 & 1 & 0 & 0,5 & 0,33 \\ 0,5 & 1 & 1 & 1 & 0,67 \\ 0,5 & 0 & 0 & 0,5 & 0,67\end{array}\right]$

2. Menghitung fungsi preferensi

\section{C1 = Etika}

$\mathrm{Pij}(1,2)$ if $0.5<0$ false, else if $0.5>0$ true, then $\mathrm{P} 1(1,2)=0.5-0=0.5$

$\mathrm{Pij}(1,3)$ if $0.5 \leq 0.5$ true, then $\mathrm{P} 1(1,3)=0$

$\mathrm{Pij}(1,4)$ if $0.5<1$ true, then $\mathrm{P} 1(1,4)=0$

$\mathrm{Pij}(1,5)$ if $0.5 \leq 0.5$ true, then $\mathrm{P} 1(1,5)=0$

$\mathrm{Pij}(1,6)$ if $0.5 \leq 0.5$ true, then $\mathrm{P} 1(1,6)=0$

$\mathrm{Pij}(1,7)$ if $0.5<0$ false, else if $0.5>0$ true, then $\mathrm{P} 1(1,7)=0.5-0=0.5$

$\mathrm{Pij}(1,8)$ if $0.5 \leq 0.5$ true, then $\mathrm{P} 1(1,8)=0$

$\mathrm{Pij}(1,9)$ if $0.5 \leq 0.5$ true, then $\mathrm{P} 1(1,9)=0$

$\mathrm{Pij}(1,10)$ if $0.5 \leq 0.5$ true, then $\mathrm{P} 1(1,10)=0$

3. Menghitung fungsi preferensi agregat dengan mempertimbangkan bobot

Tabel 10. Nilai Preferensi Agrerat

\begin{tabular}{llllllllllll}
\hline Alternatif & E & KB & PD & PS & U & Alternatif & E & KB & PD & PS & U \\
\hline PJ $(1,2)$ & 0.5 & 0.5 & 0 & 0.5 & 0 & PJ $(6,1)$ & 0 & 0 & 0 & 0 & 0 \\
PJ $(1,3)$ & 0 & 0 & 0 & 0.5 & 0.67 & PJ $(6,2)$ & 0.5 & 0 & 0 & 0.5 & 0 \\
PJ $(1,4)$ & 0 & 0 & 0 & 0 & 0 & PJ $(6,3)$ & 0 & 0 & 0 & 0.5 & 0.33 \\
PJ $(1,5)$ & 0 & 0.5 & 0 & 0 & 0.34 & PJ $(6,4)$ & 0 & 0 & 0 & 0 & 0 \\
PJ $(1,6)$ & 0 & 1 & 0 & 0 & 0.34 & PJ $(6,5)$ & 0 & 0 & 0 & 0 & 0 \\
PJ $(1,7)$ & 0.5 & 0.5 & 0 & 0.5 & 0.34 & PJ $(6,7)$ & 0.5 & 0 & 0 & 0.5 & 0 \\
PJ $(1,8)$ & 0 & 0 & 0 & 0 & 0.34 & PJ $(6,8)$ & 0 & 0 & 0 & 0 & 0 \\
PJ $(1,9)$ & 0 & 0 & 0 & 0 & 0 & PJ $(6,9)$ & 0 & 0 & 0 & 0 & 0 \\
PJ $(1,10)$ & 0 & 1 & 0 & 0 & 0 & PJ $(6,10)$ & 0 & 0 & 0 & 0 & 0
\end{tabular}




\begin{tabular}{|c|c|c|c|c|c|c|c|c|c|c|c|}
\hline $\mathrm{PJ}(2,1)$ & 0 & 0 & 1 & 0 & 0.33 & PJ $(7,1)$ & 0 & 0 & 0 & 0 & 0 \\
\hline $\mathrm{PJ}(2,3)$ & 0 & 0 & 1 & 0 & 1 & PJ $(7,2)$ & 0 & 0 & 0 & 0 & 0 \\
\hline $\mathrm{PJ}(2,4)$ & 0 & 0 & 1 & 0 & 0.33 & PJ $(7,3)$ & 0 & 0 & O & 0 & 0.33 \\
\hline $\mathrm{PJ}(2,5)$ & 0 & 0 & 1 & 0 & 0.67 & PJ $(7,4)$ & 0 & 0 & 0 & 0 & 0 \\
\hline $\mathrm{PJ}(2,6)$ & 0 & 0.5 & 1 & 0 & 0.67 & PJ $(7,5)$ & 0 & 0 & 0 & 0 & 0 \\
\hline $\mathrm{PJ}(2,7)$ & 0 & 0 & 1 & 0 & 0.67 & PJ $(7,6)$ & 0 & 0.5 & ) & 0 & 0 \\
\hline $\mathrm{PJ}(2,8)$ & 0 & 0 & 1 & 0 & 0.67 & PJ $(7,8)$ & 0 & 0 & & 0 & 0 \\
\hline $\mathrm{PJ}(2,9)$ & 0 & 0 & 0 & 0 & 0.33 & PJ $(7,9)$ & 0 & 0 & 0 & 0 & 0 \\
\hline $\mathrm{PJ}(2,10)$ & 0 & 0.5 & 1 & 0 & 0.33 & $\mathrm{PJ}(7,10)$ & 0 & 0.5 & 0 & 0 & 0 \\
\hline $\mathrm{PJ}(3,1)$ & 0 & 0 & 0 & 0 & 0 & PJ $(8,1)$ & 0.5 & 0 & U & 0 & 0 \\
\hline $\mathrm{PJ}(3,2)$ & 0.5 & 0.5 & 0 & 0 & 0 & PJ $(8,2)$ & 1 & 0.5 & & 0.5 & 0 \\
\hline $\mathrm{PJ}(3,4)$ & 0 & 0 & 0 & 0 & 0 & PJ $(8,3)$ & 0.5 & 0 & 0 & 0.5 & 0.33 \\
\hline $\mathrm{PJ}(3,5)$ & 0 & 0.5 & 0 & 0 & 0 & PJ $(8,4)$ & 0 & 0 & 0 & 0 & 0 \\
\hline $\mathrm{PJ}(3,6)$ & 0 & 1 & 0 & 0 & 0 & PJ & 0.5 & 0.5 & & 0 & 0 \\
\hline $\mathrm{PJ}(3,7)$ & 0.5 & 0.5 & 0 & 0 & 0 & PJ $(8,6)$ & 0.5 & 1 & U & 0 & 0 \\
\hline $\mathrm{PJ}(3,8)$ & 0 & 0 & 0 & 0 & 0 & PJ $(8,7)$ & 1 & 0.5 & 0 & 0.5 & 0 \\
\hline PJ $(3,9)$ & 0 & 0 & 0 & 0 & 0 & PJ $(8,9)$ & 0.5 & 0 & 0 & 0 & 0 \\
\hline $\mathrm{PJ}(3,10)$ & 0 & 1 & 0 & 0 & 0 & $\mathrm{PJ}(8,10)$ & 0.5 & 1 & & 0 & 0 \\
\hline $\mathrm{PJ}(4,1)$ & 0.5 & 0 & 0 & 0.5 & 0 & PJ $(9,1)$ & 0 & 0 & 1 & 0.5 & 0 \\
\hline $\mathrm{PJ}(4,2)$ & 1 & 0.5 & 0 & 1 & 0 & PJ $(9,2)$ & 0.5 & 0.5 & 0 & 1 & 0 \\
\hline $\mathrm{PJ}(4,3)$ & 0.5 & 0 & 0 & 1 & 0.67 & $\mathrm{PJ}$ & 0 & 0 & 1 & 1 & 0.67 \\
\hline $\mathrm{PJ}(4,5)$ & 0.5 & 0.5 & 0 & 0.5 & 0.34 & PJ $(9,4)$ & 0 & 0 & 1 & 0 & 0 \\
\hline $\mathrm{PJ}(4,6)$ & 0.5 & 1 & 0 & 0.5 & 0.34 & PJ $(9,5)$ & 0 & 0.5 & 1 & 0.5 & 0.34 \\
\hline $\mathrm{PJ}(4,7)$ & 1 & 0.5 & 0 & 1 & 0.34 & PJ $(9,6)$ & 0 & 1 & I & 0.5 & 0.34 \\
\hline $\mathrm{PJ}(4,8)$ & 0 & 0 & 0 & 0.5 & 0.34 & PJ & 0.5 & 0.5 & 1 & 1 & 0.34 \\
\hline $\mathrm{PJ}(4,9)$ & 0.5 & 0 & 0 & 0 & 0 & $\mathrm{PJ}(9,8)$ & 0 & 0 & 1 & 0.5 & 0.34 \\
\hline $\mathrm{PJ}(4,10)$ & 0.5 & 1 & 0 & 0.5 & 0 & PJ $(9,10)$ & 0 & 1 & 1 & 0.5 & 0 \\
\hline $\mathrm{PJ}(5,1)$ & 0 & 0 & 0 & 0 & 0 & $\mathrm{PJ}(10,1)$ & 0 & 0 & 0 & 0 & 0 \\
\hline $\mathrm{PJ}(5,2)$ & 0.5 & 0 & 0 & 0.5 & 0 & $\mathrm{PJ}(10,2)$ & 0.5 & 0 & 0 & 0.5 & 0 \\
\hline $\mathrm{PJ}(5,3)$ & 0 & 0 & 0 & 0.5 & 0.33 & PJ $(10,3)$ & 0 & 0 & 0 & 0.5 & 0.67 \\
\hline $\mathrm{PJ}(5,4)$ & 0 & 0 & 0 & 0 & 0 & PJ $(10,4)$ & 0 & 0 & 0 & 0 & 0 \\
\hline $\mathrm{PJ}(5,6)$ & 0 & 0.5 & 0 & 0 & 0 & PJ $(10,5)$ & 0 & 0 & 0 & 0 & 0.34 \\
\hline $\mathrm{PJ}(5,7)$ & 0.5 & 0 & 0 & 0.5 & 0 & $\mathrm{PJ}(10,6)$ & 0 & 0 & 0 & 0 & 0.34 \\
\hline $\mathrm{PJ}(5,8)$ & 0 & 0 & 0 & 0 & 0 & $\mathrm{PJ}(10,7)$ & 0.5 & 0 & 0 & 0.5 & 0.34 \\
\hline $\mathrm{PJ}(5,9)$ & 0 & 0 & 0 & 0 & 0 & PJ $(10,8)$ & 0 & 0 & 0 & 0 & 0.34 \\
\hline $\mathrm{PJ}(5,10)$ & 0 & 0.5 & 0 & 0 & 0 & $\mathrm{PJ}(10,9)$ & 0 & 0 & 0 & 0 & 0 \\
\hline
\end{tabular}

Perhitungan indeks preferensi menggunakan persamaan ke 3

$(1,2)=\sum(0.35 * 0.5)+(0.25 * 0.5)+(0.20 * 0)+(0.15 * 0.5)+(0.05 * 0)=0.375$

$(1,3)=\sum(0.35 * 0)+(0.25 * 0)+(0.20 * 0)+(0.15 * 0.5)+(0.05 * 0.67)=0.1085$

$(1,4)=\sum(0.35 * 0)+(0.25 * 0)+(0.20 * 0)+(0.15 * 0)+(0.05 * 0)=0$

$(1,5)=\sum(0.35 * 0)+(0.25 * 0.5)+(0.20 * 0)+(0.15 * 0)+(0.05 * 0.34)=0.142$

$(1,6)=\sum(0.35 * 0)+(0.25 * 1)+(0.20 * 0)+(0.15 * 0)+(0.05 * 0.34)=0.267$

$(1,7)=\sum(0.35 * 0.5)+(0.25 * 0.5)+(0,20 * 0)+(0.15 * 0.5)+(0.05 * 0.34)=0.392$

$(1,8)=\sum(0.35 * 0)+(0.25 * 0)+(0.20 * 0)+(0.15 * 0)+(0.05 * 0.34)=0.017$

$(1,9)=\sum(0.35 * 0)+(0.25 * 0)+(0.20 * 0)+(0.15 * 0)+(0.05 * 0)=0$

$(1,10)=\sum(0.35 * 0)+(0.25 * 1)+(0.20 * 0)+(0.15 * 0)+(0.05 * 0)=0.25$

Tabel 11. Matriks Agregat

\begin{tabular}{llllllllllll}
\hline & A1 & A2 & A3 & A4 & A5 & A6 & A7 & A8 & A9 & A10 & Total \\
\hline A1 & - & 0.375 & 0.1085 & 0 & 0.142 & 0.267 & 0.392 & 0.017 & 0 & 0.25 & 1.5515 \\
A2 & 0.2165 & - & 0.25 & 0.2165 & 0.2335 & 0.1585 & 0.2335 & 0.2335 & 0.0165 & 0.3415 & 1.9 \\
A3 & 0 & 0.3 & - & 0 & 0.125 & 0.25 & 0.3 & 0 & 0 & 0.25 & 1.475 \\
A4 & 0.25 & 0.625 & 0.3585 & - & 0.392 & 0.517 & 0.642 & 0.092 & 0.175 & 0.5 & 3.5515 \\
A5 & 0 & 0.25 & 0.0915 & 0 & - & 0.125 & 0.25 & 0 & 0 & 0.125 & 0.8415 \\
A6 & 0 & 0.25 & 0.0915 & 0 & 0 & - & 0.25 & 0 & 0 & 0 & 0.5915 \\
A7 & 0 & 0 & 0.0165 & 0 & 0 & 0.125 & - & 0 & 0 & 0.125 & 0.2665 \\
A8 & 0.175 & 0.55 & 0.2665 & 0 & 0.3 & 0.425 & 0.55 & - & 0.175 & 0.425 & 2.8665 \\
A9 & 0.275 & 0.45 & 0.3835 & 0.20 & 0.417 & 0.542 & 0.667 & 0.292 & - & 0.525 & 3.7515 \\
A10 & 0 & 0.25 & 0.1085 & 0 & 0.017 & 0.017 & 0.267 & 0.017 & 0 & - & 0.6765 \\
Total & 0.9165 & 3.05 & 1.675 & 0.4165 & 1.6265 & 2.4265 & 3.5515 & 0.6515 & 0.3665 & 2.5415 & \\
\hline
\end{tabular}


4. Menentukan arus keluar dan arus outrangking

$$
\begin{aligned}
& \text { Leaving flow } \\
& \varphi^{+} \mathrm{P} 1: \frac{1}{10-1} * 1.5515=0.1723 \\
& \text { Entering flow } \\
& \varphi-\mathrm{P} 1: \frac{1}{10-1} * 0.9165=0.1018
\end{aligned}
$$

Tabel 12. Hasil dari leaving flow dan entering flow

\begin{tabular}{ccc}
\hline Alternatif & Leaving flow & Entering flow \\
\hline P1 & 0.1723 & 0.1018 \\
P2 & 0.2111 & 0.3388 \\
P3 & 0.1638 & 0.1861 \\
P4 & 0.3946 & 0.0462 \\
P5 & 0.0934 & 0.1807 \\
P6 & 0.0657 & 0.2696 \\
P7 & 0.0296 & 0.3946 \\
P8 & 0.3185 & 0.0723 \\
P9 & 0.4168 & 0.0407 \\
P10 & 0.0751 & 0.2823 \\
\hline
\end{tabular}

5. Menghitung outranking setiap alternatif

$$
\begin{aligned}
& \text { P1 }=0.1723-0.1018=0.0705 \\
& \text { P2 }=0.2111-0.3388=-0.1277 \\
& \text { P3 }=0.1638-0.1861=-0.0223 \\
& \text { P4 }=0.3946-0.0462=0.3484 \\
& \text { P5 }=0.0934-0.1807=-0.0873 \\
& \text { P6 }=0.0657-0.2696=-0.2039 \\
& \text { P7 }=0.0296-0.3946=-0.365 \\
& \text { P8 }=0.3185-0.0723=0.2462 \\
& \text { P9 }=0.4168-0.0407=0.3761 \\
& \text { P10 }=0.0751-0.2823=-0.2072
\end{aligned}
$$

Tabel 13. Hasil dari perhitungan Outranking

\begin{tabular}{ccc}
\hline Alternatif & Net Flow & Ranking \\
\hline P9 & 0.3761 & 1 \\
P4 & 0.3484 & 2 \\
P8 & 0.2462 & 3 \\
P1 & 0.0705 & 4 \\
P7 & -0.365 & 5 \\
P10 & -0.2072 & 6 \\
P6 & -0.2039 & 7 \\
P2 & -0.1277 & 8 \\
P5 & -0.0873 & 9 \\
P3 & -0.0223 & 10 \\
\hline
\end{tabular}

Berdasarkan perhitungan diatas dapat disimpulkan alternatif yang layak menjadi Finalis Duta Bahasa Sumatera Utara adalah P9 Patrial Olivert Zega dan P4 Friska Situmorang.

\section{KESIMPULAN}

Adapun kesimpulan yang diperoleh dari penelitian yang dilakukan di Balai Bahasa Sumatera Utara adalah sebagai berikut:

1. Prosedur pemilihan Finalis Duta Bahasa Sumatera Utara yang sedang berjalan pada Balai Bahasa Sumatera Utara saat ini menghasilkan nilai-nilai yang dapat memberikan gambaran dalam pengambilan keputusan, sehingga jika dewan juri melakukan penilaian, maka akan didapatkan hasil yang tepat untuk pemilihan Duta Bahasa Sumatera Utara.

2. Metode promethee II dapat digunakan dalam pemilihan Finalis Duta Bahasa Sumatera Utara pada Balai Bahasa Sumatera Utara sehingga dapat menghasilkan pengambilan keputusan dalam memilih Duta Bahasa Sumatera Utara yang bersifat objektif.

3. Aplikasi sistem pendukung keputusan dengan menggunakan Microsoft Visual Studio 2008 dalam pemilihan Finalis Duta Bahasa Sumatera Utara yang dibangun sangat membantu para dewan juri dalam melakukan 
penilaian dan pengambilan keputusan memilih Duta Bahasa Sumatera Utara pada Balai Bahasa Sumatera Utara.

\section{REFERENCES}

[1] R. I. Nurhayati Mursalin, "Sistem Pendukung Keputusan Pemilihan Duta Mahasiswa Generasi Berencana BK," vol. 9, no. 2087-1716, 2017.

[2] S. H. A. Lita Asyriati Latif, Mohamad Jamil, Sistem Pendukung Keputusan Teori Dan Implementasi. Yogyakarta, 2018.

[3] D. Nofriansyah, Multi Criteria Decision Making (MCDM) Pada Sistem Pendukung Keputusan. Yogyakarta: CV.Budi Utama, 2017.

[4] Https://id.answers.yahoo.com/question/index?qid=20100607052128AAHE7mq, "Pengertian Duta." .

[5] Https://www.zonareferensi.com/pengertian-bahasa/, "Pengertian Bahasa." .

[6] Https://news.okezone.com/read/2012/11/01/373/712083/duta-bahasa-cermin-pemuda-peduli-bahasa-indonesia,"Duta Bahasa, Cermin Pemuda Peduli Bahasa Indonesia.".

[7] Kneza Mihaila, Balkan Conference On Operational Research. Serbia: Institute Of The Serbian Academy Of Sciences And Arts (SANU), 2018.

[8] dan I. S. Mesran, Pristiwanto, "Implementasi Promethee II Dalam Pemilihan Pestisida Terbaik Untuk Perawatan Daun Pada Tanaman Cabe," vol. 3, no. 2502-7131, 2018. 